TEKNIK, 41 (1), 2020, 27-39

\title{
Peningkatan Kekuatan Sifat Mekanis Komposit Serat Alam menggunakan Serat Enceng Gondok (Tinjauan Pustaka)
}

\author{
Sulardjaka*, Sri Nugroho, Rifky Ismail \\ Departemen Teknik Mesin Fakultas Teknik, Universitas Diponegoro, \\ Jl. Prof. Soedarto, SH, Kampus UNDIP Tembalang, Semarang, Indonesia 50275
}

\begin{abstract}
Abstrak
Enceng gondok (Eichhornia crassipes) merupakan tumbuhan perairan yang memiliki laju pertumbuhan cepat. Pertumbuhan populasi yang tinggi menyebabkan berbagai persoalan yang menyangkut gangguan keseimbangan ekosistem, gangguan irigasi dan sedimentasi. Enceng gondok memiliki potensi untuk diaplikasikan dalam pembuatan komposit serat alam. Serat selulosa dari tanaman enceng gondok dapat dimanfaatkan sebagai penguat pada pembuatan komposit. Kajian pustaka ini bertujuan untuk memberikan kajian potensi pengembangan pemanfaatan serat enceng gondok dalam pembuatan komposit serat alam. Pemanfaatan serat enceng gondok sebagai penguat komposit untuk aplikasi komersial masih sangat terbatas. Hal ini disebabkan sifat mekanis yang dihasilkan masih rendah. Untuk mendapatkan kekuatan komposit yang semakin meningkat, diperlukan penerapan dan optimasi parameter proses pengolahan serat, perlakuan awal serat dalam pembuatan komposit serat enceng gondok. Kajian pustaka ini selain memberikan kajian literatur tentang sifat fisis dan mekanis komposit serat enceng gondok yang telah dihasilkan juga memberikan kajian literatur tentang faktor yang mempengaruhi sifat serat alam, sifat kimia, sifat fisis, sifat mekanis, proses pembuatan serat, dan perlakuan serat sehingga hasil penelitian tersebut dapat digunakan rujukan dalam pengembangan komposit dengan penguat serat enceng gondok.
\end{abstract}

Kata kunci: serat enceng gondok; komposit serat alam; sifat mekanis; sifat fisis; sifat kimia; penguatan

\begin{abstract}
[Title: Enhancing the Strength of Mechanical Properties of Natural Fiber Composites Using Water Hyacinth Fiber: A Review] Water Hyacinth/Eichhornia crassipes (WH) is an aquatic plant that has high growth. High grow of WH caused many problems such as ecosystem, irrigation, and sedimentation. WH has potential application in natural fiber composite (NFC) by using its cellulose fiber as raw material for composite production. The used of WH as reinforcement for the natural composite in industrial aplication is still limited. This is due to the low mechanical properties produced. This review aims to provide an overview of the physical and mechanical properties of WH reinforced composites and the possibilities using WH fiber in the manufacturing of NFC. Overview of the factors that affect the mechanical performance WH fiber, chemical, physical, and mechanical properties, manufacturing WH fibers, and properties of NFC.
\end{abstract}

Keywords: water hyacinth fiber; natural fiber composite; physical properties; mechanical properties, chemical properties; enhancing the strength

\section{Pendahuluan}

Penelitian dan inovasi dalam bidang komposit serat alam mengalami perkembangan yang pesat. Hal ini dikarenakan serat alam memiliki kelebihan

\footnotetext{
*) Penulis Korespondensi.

e-mail: sulardjaka@lecturer.undip.ac.id
}

dibandingkan dengan komposit serat sintesis (serat gelas, serat kevlar). Kelebihan penggunaan komposit serat alam diantaranya adalah dampak terhadap lingkungan yang rendah, dapat diperbaharui, murah, mudah terdegradasi serta dapat digunakan pada berbagai aplikasi (Jiang \& Hinrichsen, 1999; Elanchezhian dkk, 2016; Siengchin, 2017; Sanjay $d k k$., 2018). Penggunaan 


\section{TEKNIK, 41 (1), 2020, 28}

serat alam sebagai penguat pada komposit masih mengalami berbagai permasalahan. Kelemahan serat alam sebagai penguat komposit antara lain: sifat mekanis yang rendah, sifat hidrofilik, temperatur proses terbatas, gaya ikat matrik dan serat yang rendah dan mudah terdegradasi (Athijayamani dkk., 2009; Sanjay \& Siengchin, 2018; Jawaid \& Khalil, 2011). Untuk mengatasi hal tersebut, penelitian untuk meningkatkan sifat serat alam untuk penguat pada komposit mulai dilakukan. Salah satu metode untuk mendapatkan penguatan yang baik dari serat alam, dapat dilakukan dengan perlakuan awal serat ataupun dengan merekayasa metode pembuatan serat alam (Faruk $d k k .$, 2012; Sanjay, $d k k .$, 2019). Beberapa serat alam telah dikembangkan sebagai penguat komposit. Serat yang diambil dari kulit/batang tanaman seperti: rami, kenaf dan rosela (Giridharan, 2019; Yuan $d k k$., 2016; Guo dkk., 2019; Hamidon $d k k$., 2019; Kian, $d k k$., 2019). Serat yang diambil dari daun tanaman seperti: nanas, sisal dan abaka (Bahra, $d k k ., 2017$; Yusof, $d k k$., 2015; Cai, $d k k$., 2016). Serat kapuk yang diambil dari biji, atau serat lain seperti: sabut kelapa (diekstraksi dari buah), bambu, rumput gajah (diekstraksi dari tangkai) dan lain-lain (Bismarck $d k k$., 2005; Thomas $d k k ., 2015$; Madhu $d k k ., 2018)$.

Enceng gondok (Eichhornia crassipes) adalah jenis tanaman air yang hidup mengambang dipermukaan air. Tanaman ini tumbuh secara agresif dan menjadi gangguan di hampir seluruh benua selama lebih dari 100 tahun. Bahkan enceng gondok digolongkan dalam daftar 100 paling spesies invasif berbahaya di dunia. Pertumbuhan populasi yang tinggi menyebabkan berbagai persoalan yang menyangkut gangguan keseimbangan ekosistem, menurunnya produksi ikan, hilangnya organisme endemik, gangguan irigasi dan sedimentasi/pendangkalan (EPPO, 2008; Teygeler, 2000; Amanda, 2011; Sindhu $d k k ., 2017$; Hidayati $d k k ., 2018$; Indrayati \& Hikmah, 2018). Selama beberapa dekade terakhir, banyak dilakukan penelitian untuk mendapatkan metode yang efektif dalam mengontrol pertumbuhan tanaman enceng gondok seperti: pemindahan mekanis, herbisida kimia, pengenalan predator alami atau dengan mengembangkan metode pemanfaatkan tanaman enceng gondok. Berbagai penelitian untuk memanfaatkan tanaman enceng gondok sudah dilakukan. Tanaman enceng gondok telah diteliti untuk dimanfaatkan sebagai: penyerap logam berat, menyerap limbah pewarna, bahan biofuel maupun biogas dan penguat pada komposit (Gao, dkk., 2013; Gupta, A. \& Balomajumder, 2015; Rani, dkk., 2015; Choudhary, dkk., 2015; Romanova dkk., 2016; Pickering $d k k$., 2016; Sindhu $d k k$., 2017; Widhata $d k k$., 2019).

doi: $10.14710 /$ teknik.v41n1.23473
Penggunaan bahan enceng gondok sebagai penguat pada komposit masih memerlukan kajian lebih lanjut. Permasalahan yang timbul dari bahan enceng gondok adalah: kekuatan mekanis yang rendah, mudah menyerap air sehingga menurunkan ikatan serat dengan matrik, kompatibilitas serat enceng gondok dengan matrik polimer rendah (Abral $d k k ., 2014$; Tan, $d k k$., 2015; Tan \& Supri , 2016; Sindhu $d k k$., 2017). Hasil penelitian tersebut menunjukkan bahwa sifat mekanis komposit yang dihasilkan relatif rendah. Namun, komposit dengan penggunaan serat enceng gondok sebagai penguat komposit memiliki kelebihan lain yaitu meningkatkan kemampuan peredaman akustik dan resistansi termal yang baik (Wijayanti $d k k$., 2015; Abral, dkk., 2018).

Artikel ini bertujuan untuk memberikan kajian literatur tentang komposit dengan penguat serat enceng gondok. Artikel diawali dengan kajian tentang sifat serat enceng gondok yang meliputi: sifat fisis, kimia dan mekanis. Proses ekstraksi tanaman enceng gondok untuk digunakan sebagai penguat komposit. Hasil penelitian tentang sifat mekanis komposit dengan penguat enceng gondok. Metode perlakuan terhadap serat alam atau serat enceng gondok untuk meningkatkan sifat fisis, mekanis dan kompatibilitas serat sehingga meningkatkan sifat mekanis komposit yang dihasilkan. Kajian pustaka ini diharapkan dapat menjadi rujukan bagi penelitian pengembangan komposit dengan penguat serat enceng gondok.

\section{Metode Penelitian}

Untuk mencapai tujuan penulisan artikel ini, dilakukan penelusuran literatur dengan menggunakan berbagai sumber. Percairan sumber pustaka utama dilakukan melalui mesin percarian seperti: Google Cendekia, SCOPUS, research gate dan ISI Web of Knowledge. Sebagian besar referensi dipilih dari artikel yang terbit dari penerbit terindeks. Keseluruhan rujukan merupakan ruajukan dari sumber primer. Artikel dari jurnal nasional, prosiding seminar nasional maupun referensi lain dipilih berdasarkan kesesuaian dengan tema kajian literatur. Penelusuran literatur, menggunakan kata kunci "eceng gondok (water hyacinth)", "komposit serat alam (natural fibel composites)", "komposit serat enceng gondok (water hyacinth composites)", "serat alam (natural fiber)" dan pengolahan serat alam (pre-treatment natural fiber)".

\section{Hasil dan Pembahasan \\ 3.1. Sifat Serat Enceng Gondok}

Sifat serat alam dipengaruhi oleh berbagai faktor. Faktor yang mempengaruhi sifat serat alam antara lain: kondisi pertumbuhan tanaman (spesies tanaman, lokasi tanaman dan kondisi iklim setempat), masa panen (umur serat, ketebalan serat) dan tahapan 


\section{TEKNIK, 41 (1), 2020, 29}

penyediaan (metode pengiriman, kondisi penyimpanan, lama penyimpanan) (Dittenber dan Ganga Rao, 2012; Thakur dan Thakur, 2014). Sebagai serat alam, karakteristik serat enceng gondok juga dipengaruhi oleh hal tersebut. Berikut disajikan beberapa penelitian yang telah mengkarakterisasi serat enceng gondok.

\subsubsection{Sifat Fisis dan Kimia}

Analisis terhadap serat enceng gondok dari tamanan enceng gondok yang tumbuh di danau Laguna de Bay Filipina menunjukkan bahwa, serat enceng gondok memiliki kandungan selulosa yang tinggi. Serat enceng gondok memiliki kandungan holoselulosa dan alfa selulosa tinggi. Serat enceng gondok memiliki jumlah holoselulosa $83,94 \%$ dan alfa selulosa $61,63 \%$. Hasil pengujian menunjukkan persentase kandungan lignin sebesar 3,87\% dan hemiselulosa (16,26\%) (Tumolva $d k k ., 2013$ ). Hasil penelitian yang dilakukan oleh Abdel-Fattah dan Abdel-Naby pada tahun 2012, menunjukkan bahwa eceng gondok yang tumbuh di Sungai Nil memiliki kandungan selulosa $60 \%$, hemiselulosa $8 \%$ dan lignin $17 \%$. Karakterisasi kimia terhadap serat enceng gondok yang diambil dari Aranmanai Kulam Dindigul, Tamilnadu, India mendapatkan enceng gondok mengandung $29 \%$ selulosa, $20 \%$ hemiselulosa, 18 persen lignin dan $21 \%$ abu (Sivasankari $d k k$., 2006). Kandungan kimia serat enceng gondok yang diambil dari Payakumbuh, Indonesia menunjukkan, bahwa serat enceng gondok dari daerah ini mengandung $43 \%$ selulosa, $29 \%$ hemiselulosa dan $7 \%$ lignin (Asrofi $d k k$., 2018). Dari berbagai penelitian tentang kandungan kimia serat enceng gondok tersebut, dapat disimpulkan bahwa serat enceng gondok mengandung selulosa berkisar antara $29-61 \%$, kandungan hemiselulosa sebesar 16 - $29 \%$, memiliki kandungan lignin 2,25 - $18 \%$. Kandungan abu yang terdapat pada serat enceng gondok berkisar antara $9-11 \%$.

Beberapa peneliti telah melakukan penelitian untuk mengetahui sifat fisis serat enceng gondok. Karakteristik yang diteliti adalah densitas dan diameter serat. Penelitian yang dilakukan oleh Bordoloi $d k k$. (2018), menunjukkan bahwa serat enceng gondok memiliki densitas sebesar $0,7 \mathrm{gr} / \mathrm{cm}^{3}$. Serat enceng gondok yang diambil dari tanaman enceng gondok dari tepi sungai Cauvery Distrik Erode, Tamilnadu, India memiliki densitas sebesar $1,22 \mathrm{gr} / \mathrm{cm}^{3}$ dengan diameter serat sebesar $819 \mu \mathrm{m}$ (Bhuvaneshwari dan Sangeetha, 2017). Hasil penelitian dari Chonsakorn pada tahun 2018 menunjukan bahwa serat enceng gondok memiliki diameter $50 \mu \mathrm{m}$.

Dari penelitian tersebut dapat disimpulkan bahwa, serat enceng gondok memiliki densitas berkisar antara $0,7-1,22 \mathrm{gr} / \mathrm{cm}^{3}$. Jika dibandingkan dengan bulu ayam, serat enceng gondok memiliki densitas yang tidak berbeda secara siginifikan (Gashti, 2013; Dittenber dan Ganga Rao, 2011; Cheng dkk., 2009). Densitas serat enceng gondok lebih rendah dibandingkan dengan densitas serat rami, serat abaka atau serat nanas yang memiliki densitas $1,5 \mathrm{gr} / \mathrm{cm}^{3}$ (Mohanty, 2000; Nam dan Netravali, 2006; Kuang, 2010; Ticoalu, 2010; Zini dan Scandola, 2011).

\subsubsection{Sifat Mekanis}

Kajian untuk melihat kelayakan pemanfaatan serat enceng gondok sebagai penguat pada bahan komposit serat alam telah banyak dilakukan. Salah satu sifat penting yang harus diteliti adalah kekuatan tarik serat enceng gondok. Serat enceng gondok memiliki kekuatan tarik sebesar $313 \mathrm{MPa}$ dengan elongasi sebesar $14 \%$ (Bordoloi $d k k$., 2018). Tumolva (2013) telah melakukan pengujian kekuatan tarik serat tunggal enceng gondok. Pengujian dilakukan berdasarkan ASTM D3379-75 dengan jumlah spesimen 20 buah. Hasil pengujian menunjukkan bahwa serat enceng gondok yang diambil dari sebuah danau di Pilipina ini, memiliki kekuatan tarik sebesar $105 \mathrm{MPa}$ dengan elongasi sebesar $3 \%$. Serat enceng gondok yang berasal dari tepi sungai Cauvery (India) diuji berdasarkan ASTM D3822 tentang pengujian serat sintesis. Hasil pengujian memberikan hasil bahwa kekuatan tarik serat enceng gondok sebesar $220 \mathrm{Mpa}$ dengan elongasi sebesar 2,8\% (Bhuvaneshwari dan Sangeetha, 2017).

Proses pengolahan serat dari enceng gondok akan menghasilkan sifat mekanis serat yang berbeda. Pengujian tarik serat tunggal dilakukan dengan menggunakan standart pengujian ASTM D3222-07. Pembuatan serat enceng gondok dengan proses: ekstraksi mekanis, mekanis dan kimia, perendaman, natural alkali, ekstraksi kimia dan perebusan menghasilkan kekuatan tarik berkisar 108,62 sampai dengan 115,26 (grams-force per denier) dengan elongasi 2,51 - 7,72 \% (Chonsakorn dkk., 2018). Perbandingan sifat mekanis serat dengan beberapa serat alam ditunjukkan pada Tabel 1. Data pada Tabel 1 selanjutnya disajikan dalam bentuk grafik seperti ditunjukkan pada Gambar 1.

Berdasarkan data pada Tabel 1 dan grafik pada Gambar 1, dapat disimpulkan bahwa kekuatan serat enceng gondok masih di bawah kekuatan serat rami, serat goni/jute atau serat sisal. Elongasi serat enceng gondok lebih tinggi jika dibanding dengan ketiga serat tersebut. Serat enceng gondok memiliki kekuatan tarik yang relatif sama jika dibanding dengan kekuatan tarik serat dari kapas atau sabut kelapa dan cenderung lebih tinggi jika dibanding kekuatan tarik serat wol dan bulu ayam. Rasio kekuatan terhadap densitas serat enceng gondok sebesar $447 \mathrm{MPa} /\left(\mathrm{gr} / \mathrm{cm}^{3}\right)$. 


\section{TEKNIK, 41 (1), 2020, 30}

Tabel 1. Sifat Mekanis Beberapa Serat Alam.

\begin{tabular}{lcc}
\hline Nama serat & $\begin{array}{c}\text { Kekuatan tarik } \\
(\mathbf{M P a})\end{array}$ & $\begin{array}{c}\text { Elongasi } \\
(\boldsymbol{\%})\end{array}$ \\
\hline Rami & $400-938$ & $2,0-3,8$ \\
Goni/Jute & $393-800$ & $1,5-1,8$ \\
Sisal & $507-855$ & $2,0-2,5$ \\
Kapas & $287-800$ & $3,0-10$ \\
Wol & $50-315$ & $13,2-35$ \\
Sabut & $131-220$ & $15-30$ \\
Bulu ayam & $100-203$ & 6,9 \\
Enceng gondok & $105-313$ & $2,51-14$ \\
\hline Sun
\end{tabular}

Sumber: Athijayamani $d k k .(2009)$; Pickering $d k k$, (2016); Tumolva (2013); Bordoloi dkk. (2018), Chonsakorn dkk. (2018), Gashti (2013), Dittenber \& Ganga Rao (2011), Cheng $d k k$. (2009)

\subsection{Pembuatan Serat Enceng Gondok.}

Salah satu hal penting dalam pembuatan komposit serat alam adalah proses ekstraksi serat dari tanamannya. Proses ekstrasi berpengaruh terhadap sifat mekanis serat dan akhirnya mempengaruhi sifat komposit yang dihasilkan. Proses ekstrasi/pembuatan serat ini bertujuan untuk memisahkan serat tanaman dari lapisan lilin, pektin, hemiselulosa dan lignin. Ada berbagai metoda yang telah diterapkan untuk membuat/mengekstrasi serat tanaman dari tanaman induknya, yaitu: dengan perendaman, metode kimia ataupun metode mekanis.

Metode perendaman merupakan metode yang mudah dan umum digunakan untuk membuat serat. Pada proses ini, tanaman direndam dalam air. Batang enceng gondok direndam di dalam air untuk menghilangkan lignin, lapisan lilin, hemiselulosa, dan kotoran lain yang menempel pada batang. Air akan masuk hingga ke dalam bagian dalam tanaman, mengakibatkan sel-sel di dalam tanaman membengkak hingga serat terpisah dari ligninnya. Batang enceng gondok direndam di dalam air selama 7 hari untuk menghilangkan lignin, lapisan lilin, hemiselulosa, dan kotoran lain yang menempel pada batang (Tumolva, $d k k$., 2013). Pemisahan serat dengan metode ini memerlukan waktu 14 - 28 hari (Sanjay, $d k k$. 2019). Menurut Manimaran $d k k$. (2018) metode ini menghasilkan serat dengan kualitas yang rendah. Proses dengan perendaman selain memerlukan waktu lama, juga berpotensi mencemari lingkungan (Riberio, $d k k ., 2018$ ).

Ekstraksi serat dengan metode mekanis, memberikan kualitas serat yang baik dan waktu proses yang pendek, namun metode ini lebih mahal jika dibanding dengan metode perendaman (Paridah, $d k k$, 2011). Salah satu mentode ekstraksi serat enceng gondok secara mekanis adalah dengan menyikat batang enceng gondok dengan menggunakan sikat kawat

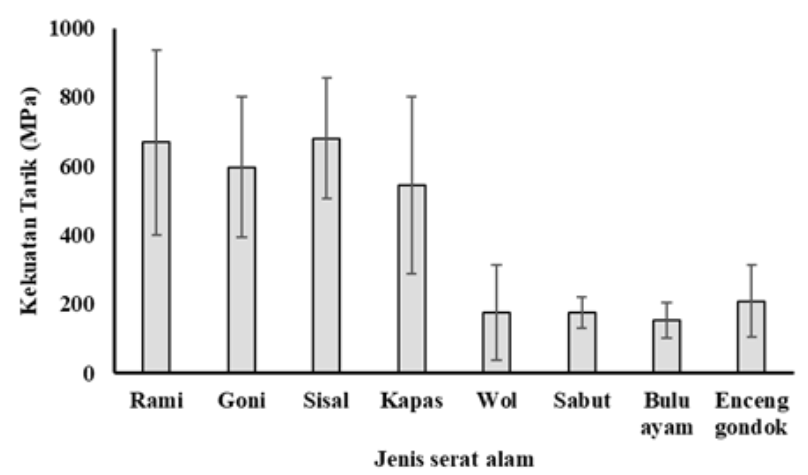

Gambar 1. Kekuatan Tarik Beberapa Serat Alam (Pickering $d k k$., 2016; Tumolva, 2013; Bordoloi $d k k$., 2018; Chonsakorn dkk., 2018; Gashti, 2013; Dittenber dan Ganga Rao, 2011; Cheng $d k k ., 2009$ ).

(Prasetyaningrum dkk, 2009; Aji, dkk, 2018). Metode pengolahan tanaman enceng gondok secara mekanis juga dapat dilakukan dengan memotong, mengeringkannya dengan sinar matahari kemudian menggiling dengan rotary mill. Proses ini menghasilkan serat tanaman enceng gondok berukuran sekitar $70 \mu \mathrm{m}$ (Potiyaraj, dkk., 2001; Supri, $d k k$. 2013). Serat enceng gondok juga dibuat dengan mengeringkan tanaman enceng gondok. Kemudian digerus hingga menjadi serbuk (Supri \& Ismail 2011). Ektraksi tanaman enceng gondok dengan secara ekstraksi mekanis juga dapat dilakukan dengan menggunakan roller (Chonsakorn, 2018). Tanaman enceng gondok yang telah kering, juga dapat diekstraksi dengan menggunakan tangan secara langsung (Huda, 2017). Karena diperoleh dengan metode penggerusan, penguatan tanaman enceng gondok pada sifat mekanis komposit tidak optimal. Hasil ekstraksi tanaman enceng gondok pada komposit lebih berperan sebagai pengisi, bukan penguat, sehingga sifat mekanis yang dihasilkan lebih rendah.

Ekstraksi serat enceng gondok nanofiber dilakukan dengan kombinasi proses kimia dan mekanis. Pada tahap awal potongan tanaman enceng gondok direndam pada larutan toluene selama 6 jam, kemudian digiling. Untuk mendapatkan serat selulosa murni, hasil dari proses tersebut di-ball mill kemudian dikeringkan. Setelah proses pencucian didapatkan serat enceng gondok dengan diameter $25 \mathrm{~nm}$ (Sundari \& Ramesh, 2012).

\subsection{Komposit Serat Enceng Gondok}

Beberapa peneliti telah melakukan penelitian komposit dengan menggunakan penguat dari tanaman enceng gondok. Khankham, $d k k$, pada tahun 2017, meneliti sifat mekanis biokomposit dengan penguat dari tanaman enceng gondok. Pada penelitian ini batang enceng gondok dipotong sepanjang $3-5 \mathrm{~cm}$. 


\section{TEKNIK, 41 (1), 2020, 31}

Batang kemudian di-blender bersama air, dicuci kemudian dikeringkan dengan pengeringan oven pada suhu $40{ }^{\circ} \mathrm{C}$ selama $12 \mathrm{jam}$. Tanaman enceng gondok juga digunakan sebagai campuran pada pembuatan komposit dengan matrik semen. Pada penelitian ini, tanaman enceng gondok dikeringkan, kemudian enceng gondok kering tersebut digerus dengan tangan (SalasRuiz dan Barbero-Barrera, 2019). Hasil penelitian menunjukkan adanya penurunan densitas bahan dengan meningkatnya kandungan enceng gondok. Komposit semen dengan kandungan enceng gondok yang lebih besar memiliki sifat lentur yang lebih tinggi jika dibanding tanpa campuran.

Abral $d k k$. (2014) telah meneliti kekuatan tarik dan lentur matrik poliester yang diperkuat dengan serat enceng gondok. Pengaruh fraksi volume serat terhadap kekuatan tarik komposit poliester yang diperkuat dengan serat enceng gondok juga telah diteliti oleh Simanjuntak (2013). Grafik pengaruh fraksi volume serat terhadap kekuatan tarik komposit ditunjukkan pada Gambar 2. Hasil penelitian menunjukkan bahwa fraksi volume serat yang semakin meningkat menurunkan kekuatan tarik komposit (Abral $d k k$., 2014). Hasil penelitian tersebut senada dengan hasil penelitian Saha (2011) yang menggunakan bahan matrik polipropilen. Penelitian tersebut menunjukkan bahwa, semakin tinggi volume serat, semakin turun kekuatan tarik komposit (Saha, 2011). Peningkatan fraksi volume serat enceng gondok dari 5, 10, $25 \%$, juga mengakibatkan menurunnya kekuatan tarik komposit (Supri \& Ismail, 2010). Hal ini berbeda dengan kecederungan hasil penelitian Simanjutak pada tahun 2013. Penelitian ini menunjukkan bahwa pada peningkatan fraksi volume serat dari $20 \%$ ke $30 \%$, kekuatan tarik komposit meningkat.

Komposit dengan menggunakan matrik poripropilen dan polipropilen hasil daur ulang dengan perbandingan antara serat enceng gondok dan bahan matrik sebesar 50:50, menghasilkan kekuatan tarik sebesar 14,72 MPa dan 13,69 (Karina $d k k$., 2007). Penggunaan matrik polietilen yang didaur ulang dengan menggunakan penguat batang enceng gondok yang dipotong dengan ukuran $1 \mathrm{~mm}$, menghasilkan kekuatan tertinggi sebesar $17 \mathrm{MPa}$, pada persentase enceng gondok 2,5\%. Serat enceng gondok juga digunakan sebagai penguat pada komposit orthophthalic polyester (ortho-UP) resin. Proses pembuatan komposit dilakukan dengan metode hand lay-up. Produk komposit kemudian di-cure pada temperatur $150{ }^{\circ} \mathrm{C}$ selama 3 jam. Karakterisasi mekanis komposit tersebut menghasilkan kekuatan tarik komposit sebesar $105 \mathrm{MPa}$ dan kekuatan lentur 190 MPa (Tumolva, $d k k$., 2013).

Batang enceng gondok juga telah diteliti sebagai penguat komposit dengan menggunakan matrik campuran antara poliester dan ampas singkong (Karyanik dan Sari, 2016). Pada penelitian ini batang enceng gondok dicuci dan dikeringkan selama 2 jam, disikat dengan sikat kawat kemudian dipotong sepanjang $25 \mathrm{~cm}$. Kemudian batang enceng gondok tersebut dimanfaatkan sebagai serat

penguat pada matrik campuran poliester dan ampas singkong. Penelitian ini menghasilkan komposit dengan kekuatan tarik tertinggi sebesar $19 \mathrm{MPa}$. Suryana dkk (2018) menggunakan enceng gondok hingga fraksi massa 30,50 dan $70 \%$ pada matrik campuran poliester dan pasir silika untuk digunakan sebagai point untuk panjat dinding. Penelitian ini menghasilkan komposit dengan kekuatan tarik tertinggi adalah pada penambahan $50 \%$ serat yaitu sebesar: 17 MPa. Pada matrik LDPE, penambahan serat enceng gondok sampai dengan fraksi massa $20 \%$ memberikan peningkatan kekuatan tarik hingga sekitar $25 \%$. Penambahan serat enceng gondok $25 \%$ menurunkan kekuatan tarik komposit (Potiyaraj, $d k k$., 2001). Serat enceng gondok juga telah diteliti untuk dimanfaatkan sebagai pengisi pada karet alam. Hasil penelitian menunjukkan bahwa serat enceng gondok memberikan peningkatan sifat mekanis (kekerasan dan modulus elastisitas) pada karet (Potiyaraj, $d k k ., 2001$ ).

Gambar 3. menunjukkan pengaruh fraksi volume serat terhadap kekuatan lentur komposit dengan penguat serat enceng gondok. Matrik yang digunakan adalah poliester (Abral $d k k$., 2014; Ramirez $d k k ., 2015)$ dan polipropilen (Saha, 2011). Grafik tersebut menunjukkan bahwa fraksi volume serat yang meningkat, memberikan kekuatan lentur yang semakin rendah. Penelitian Ramires (2015) bahkan menunjukkan adanya penurunan kekuatan lentur yang cukup tinggi jika dibandingkan dengan bahan matrik. Hasil ini senada dengan penelitian Abral $d k k$. (2014) yang menunjukkan adanya penurunan kekuatan lentur yang cukup tinggi dengan meningkatnya fraksi volume serat dari $5 \%$ ke $10 \%$. Pada matrik polipropilen, peningkatan volume serat hampir tidak memberikan pengaruh yang signifikan terhadap kekuatan lentur komposit (Saha, 2011).

Selain kekuatan tarik dan lentur, beberapa peneliti juga meneliti kekuatan impak komposit dengan penguat enceng gondok. Batang enceng gondok yang dipotong sepanjang $20 \mathrm{~mm}$, digunakan sebagai penguat pada komposit. Matrik yang digunakan adalah epoxyresin. Proses pembuatan komposit dilakukan dengan hand lay-up. Proses ini menghasilkan komposit dengan kekuatan impak 0,12 J/mm² (Huda, dkk., 2017). Pengujian impak terhadap komposit poliester yang diperkuat dengan $30 \%$ serat enceng gondok, mendapatkan hasil kekuatan impak sebesar $0,1 \mathrm{~J} / \mathrm{mm}^{2}$ (Padmanabhan dkk., 2016). Berbeda dengan kecenderungan pada uji tarik dan uji lentur, hasil 


\section{TEKNIK, 41 (1), 2020, 32}

pengujian impak menunjukkan bahwa meningkatnya fraksi volume serat hingga $30 \%$, dapat meningkatkan kekuatan impak komposit polipropilen yang diperkuat dengan serat enceng gondok. Hasil kekuatan impak tertinggi yang didapat adalah $0,05 \mathrm{~J} / \mathrm{mm}^{2}$ pada komposit dengan $30 \%$ serat (Saha, 2011). Hasil ini masih $30 \%$ lebih rendah jika dibandingkan kekuatan impak komposit dengan menggunakan penguat jerami (Rafiquzzaman, $d k k$., 2017).

Perbandingan kekuatan lentur material komposit $10 \%$ serat alam dengan matrik poliester ditunjukkan pada Gambar 4. Grafik pada gambar menunjukkan bahwa kekuatan lentur poliester yang diperkuat dengan serat enceng gondok masih di bawah kekuatan lentur poliester yang diperkuat dengan serat kenaf, rami, jute, rosela dan sisal. Kekuatan tarik komposit dengan $20 \%$ penguat serat alam ditunjukkan pada Gambar 5. Dari hasil pengujian kekuatan tarik dan kekuatan lentur material komposit serat alam dengan matrik poliester seperti ditunjukkan pada Gambar 4 dan Gambar 5 tersebut, dapat disimpulkan bahwa serat enceng gondok menghasilkan kekuatan tarik dan lentur yang lebih rendah jika dibanding dengan serat alam yang lain. Hal ini juga sejalan dengan

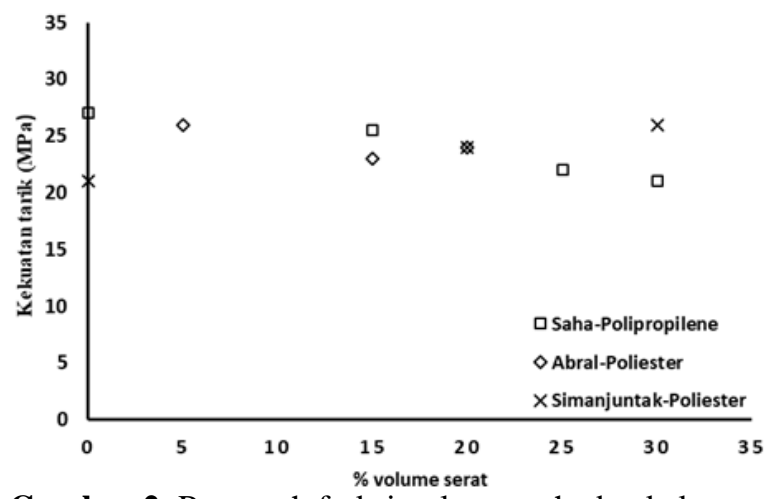

Gambar 2. Pengaruh fraksi volume terhadap kekuatan tarik komposit dengan penguat serat enceng gondok (Saha, 2011; Simanjuntak, 2013; Abral $d k k ., 2014$ )

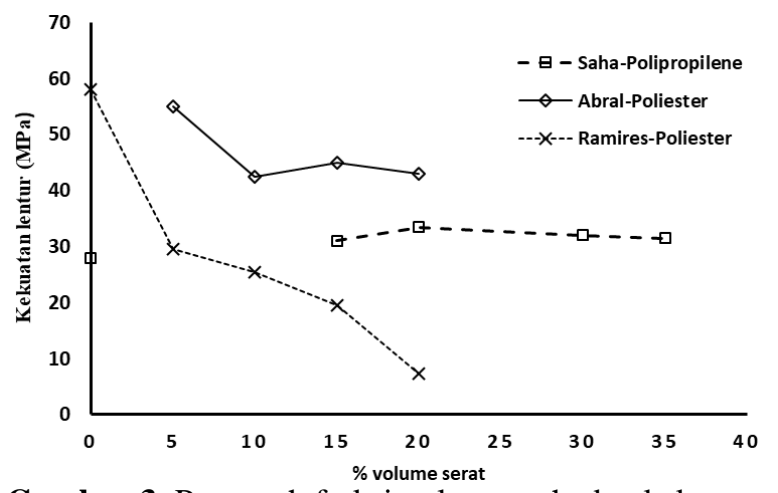

Gambar 3. Pengaruh fraksi volume terhadap kekuatan lentur komposit dengan penguat serat enceng gondok (Saha, 2011; Abral $d k k ., 2013$; Ramirez $d k k ., 2015$ ) sifat kekuatan tarik serat enceng gondok yang di bawah kekuatan tarik serat kenaf, rami, jute ataupun sisal seperti ditunjukkan pada Gambar 1.

Berdasarkan penelitian komposit dengan menggunakan penguat serat enceng gondok secara umum dapat disimpulkan bahwa peningkatan fraksi volume serat enceng gondok memberikan kecenderungan penurunan sifat mekanis komposit. Meskipun ada juga penelitian yang memberikan kecenderungan sebaliknya. Bila dikaji secara mendetil, dalam pembuatan komposit, serat enceng gondok yang ditambahkan, adalah serat dalam bentuk serat pendek atau bahkan serbuk. Hal ini mengakibatkan belum optimalnya fungsi serat enceng gondok sebagai penguat. Meskipun beberapa penelitian belum menunjukkan hasil sifat mekanis yang memuaskan, namun potensi pengembangan masih cukup menjajikan. Hal ini bisa kaji dari bentuk serat yang digunakan dalam penguat komposit. Pemrosesan tanaman enceng gondok hingga menghasilkan serat yang cukup panjang, masih sangat mungkin akan menghasilkan komposit dengan sifat mekanis yang lebih baik.

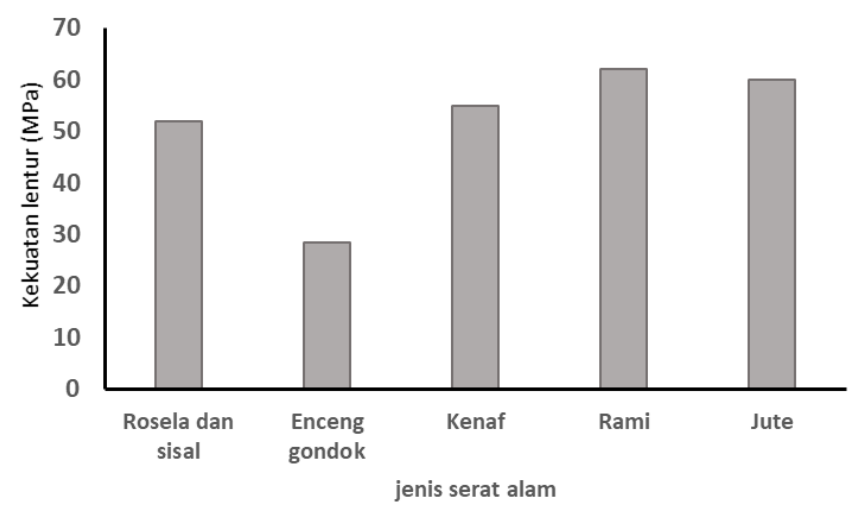

Gambar 4. Kekuatan Lentur Komposit Poliester dengan Penguat Serat Alam (Deb, $d k k$., 2017; Prasad, $d k k ., 2009$; Huda, $d k k .$, 2017, Romanzini, $d k k .$, 2012)

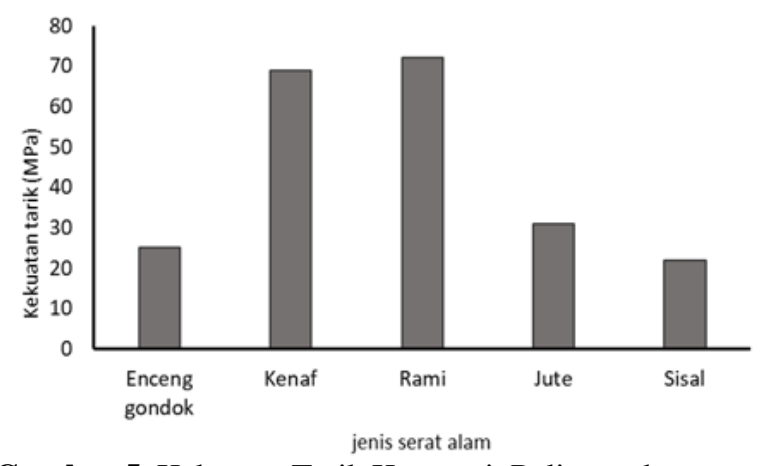

Gambar 5. Kekuatan Tarik Komposit Poliester dengan Penguat Serat Alam (Simonassi, $d k k$., 2017; Prasad, $d k k$., 2009; Hanamanagouda, $d k k$., 2016; Abral, $d k k ., 2014)$. 


\section{TEKNIK, 41 (1), 2020, 33}

\subsection{Perlakuan Serat Enceng Gondok}

Serat alam dalam aplikasinya memiliki beberapa kelemahan. Kelemahan serat alam adalah sifat mekanisnya yang relatif rendah, mudah terpengaruh lingkungan dan sifat hidrofilik. Sifat hidrofilik mengakibatkan menurunnya gaya ikat antara matrik dan serat saat serat alam digunakan sebagai penguat pada komposit. Sifat hidrofilik dapat diturunkan melalui perlakuan awal. Perlakuan awal serat alam juga dapat meningkatkan sifat fisis, kimia dan mekanis. Metode yang dapat digunakan untuk memodifikasi sifat serat alam antara lain: perendaman, kimia, alkali, silane, asetilasi, bensolisasi, peroksida, ultrasonic, microvawe, termal, mekanis dan perebusan (Valadez-Gonzalez dkk., 1999; Chonsakorn, dkk., 2018; Kabir, dkk., 2012; Faruk, 2012; Sapci, Z., 2013; Asrofi, $d k k$., 2018; Sood dan Dwivedi, 2018). Proses perlakuan kimia dengan perlakuan alkali, hidrolisa asam yang diakhiri dengan proses pencucian dapat meningkatkan komposisi selulosa hingga $70 \%$. Proses ini juga meningkatkan indeks kristalinitas serat (Asrofi, $d k k$., 2017).

Salah satu metode perlakuan serat enceng gondok adalah dengan merendam serat enceng gondok dengan larutan toluene yang mengandung isocyanate $5 \%$ selama 30 menit pada suhu $50{ }^{\circ} \mathrm{C}$. Kemudian serat dikeringkan, dan dicampur dengan toluene yang mengandung $6 \%$ polyethylene glycol. Hasil perlakuan ini menunjukkan bahwa proses tersebut mengakibatkan penurunan sifat hidrofilik serat, meningkatkan kekuatan tarik dan modulus elastisitas pada komposit LDPE/enceng gondok. Keuletan komposit pada serat non perlakuan lebih tinggi jika dibanding pada serat dengan perlakuan (Supri dan Lim, 2009). Perlakuan awal serat enceng gondok dengan silane menunjukkan bahwa, perlakuan dengan silane menurunkan sudut kontak antara serat enceng gondok dengan epoxyresin sehingga menghasilkan komposit yang lebih kuat. Perlakuan dengan coupling agen silane meningkatkan kekuatan tarik dan kekuatan lentur bahan komposit yang dihasilkan. Perlakuan dengan silane memberikan efek meningkatkan daya ikat adhesi antara serat enceng gondok dan epoxy resin (Saputra, $d k k$., 2013). Proses perlakuan

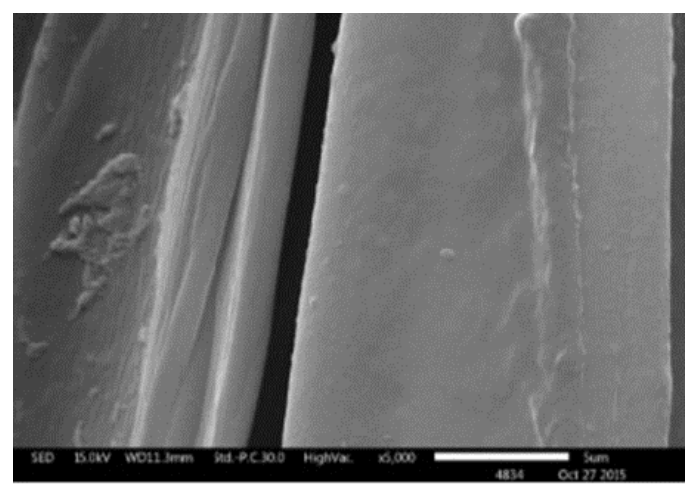

Gambar 6. Foto SEM serat enceng gondok tanpa perlakuan (Khankham, dkk, 2017) dengan alkali mengakibatkan permukaan serat enceng gondok jadi lebih kasar seperti ditunjukkan pada Gambar 6 dan Gambar 7. (Khankham, dkk, 2017). Perubahan permukaan akibat dari hilangnya sebagian gugus pektin, lignin, lilin, hidroksil dan unsur pengotor yang lain (Abral, $d k k$., 2014). Perubahan kekasaran permukaan mengakibatkan gaya interlocking antara serat dan matrik menjadi semakin baik. Hal ini mengakibatkan kekuatan tarik dan impak komposit meningkat (Varghese, A. M., \& Mittal, V. 2018; Abral, $d k k$., 2013; Kabir, $d k k$., 2012; Ku, $d k k ., 2011)$.

Perendaman serat enceng gondok pada larutan $\mathrm{NaOH} 5 \%, 10 \%$ dan $15 \%$ selama 2 jam meningkatkan elongasi serat, namun menurunkan kekuatan tarik serat. Perlakuan dengan merendam serat enceng gondok pada larutan etanol 5\%, 10\% dan 15\% selama 2 jam, juga meningkatkan elongasi namun menurunkan kekuatan tarik serat. Perendaman pada etanol $10 \%$ meningkatkan gaya interfacial antara serat enceng gondok dan poliester (Umardani dan Pramono, 2019). Hal ini berbeda dengan hasil penelitian Aji dkk (2018) yang menunjukkan bahwa peredaman kulit enceng gondok pada larutan $\mathrm{NaOH} 5 \%$ selama 1 jam, dapat meningkatkan kekuatan tarik serat tunggal enceng gondok dari $2 \mathrm{Kg} / \mathrm{mm}^{2}$ menjadi 3,5 $\mathrm{Kg} / \mathrm{mm}^{2}$.

Modifikasi terhadap sifat serat enceng gondok dapat juga dilakukan dengan menggunakan polyvinyl alcohol (PVA). Serat enceng gondok direndam dalam campuran etanol dengan serbuk PVA $6 \%$. Perendaman dilakukan selama 24 jam. Hasil pengujian menunjukkan bahwa hingga fraksi massa $25 \%$, modifikasi dengan PVA meningkatkan kekuatan tarik, modulus elastisitas dan keuletan komposit serat enceng gondok dengan matrik LDPE. Perlakuan terhadap serat enceng gondok dapat juga dilakukan dengan merendam serat ke dalam larutan toluena yang mengandung isophorone diisocyanate selama 30 menit pada suhu $50^{\circ} \mathrm{C}$. Jika dibandingkan dengan tanpa perlakukan, perlakuan ini berhasil meningkatkan kekuatan tarik komposit hingga $100 \%$ (Supri \& Ismail; 2011).

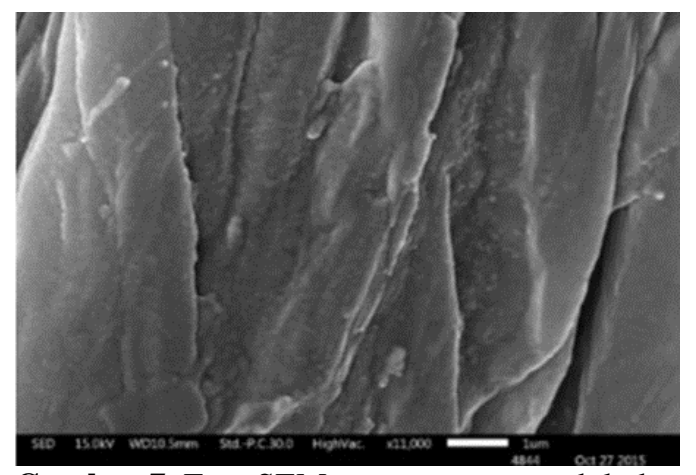

Gambar 7. Foto SEM serat enceng gondok dengan perlakuan alkali (Khankham, dkk, 2017). 


\section{TEKNIK, 41 (1), 2020, 34}

\subsection{Potensi Pengembangan}

Tanaman eceng gondok merupakan tanaman liar yang tumbuh dengan cepat dan mengganggu. Perlu dilakukan upaya untuk mengendalikan pertumbuhan tanaman enceng gondok. Peningkatan nilai ekonomis penggunaan tanaman enceng gondok akan membantu pengendalian pertumbuhan tanaman ini. Pemanfaatan serat enceng gondok sebagai penguat pada rekayasa dan pengembangan komposit serat alam memiliki prospek yang menjanjikan. Hasil penelitian sebelumnya menunjukkan bahwa kekuatan tarik dan lentur serat enceng gondok lebih rendah jika dibanding dengan serat alam yang lain seperti kenaf, jute, rami dan sisal (Pickering $d k k$., 2016; Tumolva, 2013; Bordoloi $d k k ., 2018$; Chonsakorn $d k k ., 2018$; Gashti, 2013; Dittenber dan Ganga Rao, 2011; Cheng $d k k$., 2009). Kekuatan tarik dan lentur komposit yang diperkuat serat enceng gondok juga masih lebih rendah jika dibanding dengan kekuatan tarik dan lentur komposit dengan penguat serat kenaf, jute, rami dan sisal (Simonassi, $d k k$., 2017; Prasad, dkk., 2009; Hanamanagouda, dkk., 2016; Abral, $d k k ., 2014)$.

Komposit serat alam dengan penguat serat enceng gondok masih memiliki potensi untuk dikembangkan dan ditingkatkan sifat mekanisnya. Saat ini komposit dengan penguat enceng gondok masih menggunakan batang yang dicacah, digerus atau batang yang dibelah. Penguatan yang dihasilkan oleh penguat dari tanaman enceng gondok masih sangat terbatas. Pengembangan serat enceng gondok sebagai penguat pada komposit dapat dilakukan dengan mengembangkan proses ekstraksi tanaman enceng gondok menjadi serat enceng gondok. Proses yang menghasilkan enceng gondok yang cukup panjang. Semakin penjang serat akan memberikan sifat penguatan yang lebih baik (Takagi \& Ichihara, 2004; Venkateshwaran $d k k$., 2011; Maurya $d k k$., 2015). Pada tahap berikutnya, serat tersebut dapat diproses benang. Kemudian benang dapat ditenun, sehingga mekanisme penguatan yang diberikan akan lebih baik.

Untuk meningkatkan sifat mekanis, fisis dan kompatibilitas dengan matrik, serat enceng gondok dapat diproses dengan menggunakan perlakuan awal. Beberapa penelitian menunjukkan bahwa perlakuan pada serat alam dapat meningkatkan sifat fisis, mekanis maupun kompatibilitas serat alam (Fiore $d k k$., 2016; Balachandar $d k k ., 2019$; Baley $d k k ., 2019$; Hamidon $d k k ., 2019$; Zwane $d k k ., 2019)$. Beberapa metode perlakuan awal serat, telah diteliti untuk meningkatkan sifat mekanis dan penguatan serat enceng gondok pada komposit. Hasil penelitian menunjukkan, perlakuan awal serat enceng gondok tersebut dapat meningkatkan sifat fisis dan mekanis serat enceng gondok (Supri \& Ismail; 2011; Sundari dan Ramesh 2012; Saputra, $d k k ., 2013$; Aleño, $d k k ., 2015$; Thi, $d k k ., 2017)$. Dari berbagai metode perlakuan awal serat alam, awal serat yang telah diteliti untuk meningkatkan kualitas serat enceng gondok masih sedikit. Masih banyak metode perlakuan awal serat alam yang belum diaplikasikan pada serat enceng gondok. Hal ini masih membuka peluang pengembangan peningkatan sifat fisis, kimia, mekanis serat enceng gondok dengan mengembangkan dan menggunakan beberapa metode yang telah digunakan pada serat alam yang lain.

Untuk meningkatkan pengembangan rekayasa material komposit dengan penguat serat enceng gondok, perlu dilakukan kajian mekanika mikro (micromechanics). Kajian micromachanics memberikan landasan secara teoritis yang lengkap, sehingga dapat digunakan sebagai dasar dalam pengembangan di skala makro. Hasil kajian ini dapat menghemat biaya untuk riset dan pengembangan selanjutnya. Sifat mekanis komposit dengan penguat serat enceng gondok, dapat ditingkatkan melalui pengembangan komposit hibrid. Pada penelitian ini serat enceng gondok dapat digabung dengan serat alam yang lain atau dengan serat sintesis.

\section{Kesimpulan}

Tanaman enceng gondok memiliki potensi yang besar untuk dimanfaatkan sebagai serat penguat pada pembuatan komposit serat alam. Hasil penelitian komposit poliester yang diperkuat serat enceng gondok menghasilkan kekuatan tarik sebesar $25 \mathrm{MPa}$ dan kekuatan lentur sebesar 28,5 MPa. Kekuatan tarik komposit dengan diperkuat serat enceng gondok ini berkisar $35 \%$ dari komposit dengan penguat serat rami atau kenaf. Kelemahan penggunaan tanaman enceng gondok sebagai penguat adalah belum ditemukan adanya proses preparasi/pengolahan serat dari tanaman enceng gondok yang menghasilkan serat dengan kekuatan yang tinggi. Proses perlakukan awal serat juga belum dilaksanakan secara optimal. Untuk mendapatkan sifat komposit yang lebih baik, perlu dikembangkan metode pengolahan serat, perlakuan awal serat, penelitian mekanika mikro dan teknik pembuatan komposit

\section{Ucapan Terima Kasih}

Penulis mengucapkan terima kasih kepada Direktorat Riset dan Pengabdian Masyarakat Direktorat Jenderal Penguatan Riset dan Pengembangan Kementerian Riset, Teknologi dan Pendidikan Tinggi yang telah memberikan dana penelitian ini melalui skema penelitian Tesis Magister. Berdasarkan Surat Tugas No: 258-17/UN7.P4.3/PP/2019 tanggal: 1 April 2019.

\section{Daftar Pustaka}

Abdel-Fattah, A.F., \& Abdel-Naby, M.A. (2012) Pretreatment and enzymic saccharification of water hyacinth cellulose. Carbohydrate Polymers, 87, 2109-2113.

Abral, H., Putra, H., Sapuan, S.M., \& Ishak, M.R. (2013) Effect of alkalization on mechanical properties of water hyacinth fibers-unsaturated polyester 


\section{TEKNIK, 41 (1), 2020, 35}

composites, Polymer-Plastics Technology and Engineering, 52, 446-451.

Abral, H., Kadriadi, D., Rodianus, A., Mastariyanto, P., Ilhamdi, S., Sapuan, A.S.M., \& Ishak, M.R. (2014) Mechanical properties of water hyacinth fibers polyester composites before and after immersion in water. Materials and Design. 58, 125-129.

Abral, H., Dalimunthe, M.H., Hartono, J., Efendi, R.P., Asrofi, M., Sugiarti, E., SM Sapuan, S.M., Park, J.W., Kim, H. (2018) Characterization of tapioca starch biopolymer composites reinforced with micro scale water hyacinth fibers. Starch - Stärke, 70(7-8).

Aji, T.A., Purwanto, H., \& Respati, S. M. B. (2018) Pengaruh ketebalan komposit matrik resin dengan penguat kulit eceng gondok (eichhornia crassipes) yang dianyam terhadap kemampuan balistik, Momentum, Vol. 14(1), 75-79.

Aleño, J. B., Ramos, H. J. \& Jose, W. I. (2014) Determination of Properties of yarns made from Water Hyacinth and pinneapple indigenous fibers treated using plasma enhaced chemical vapour deposition, $5^{\text {th }}$ International Conference on Chemical, Ecology and Environmental Sciences (ICCEES'2014) Jan. 13-14, Penang (Malaysia).

Amanda, P. (2011) 2030, Rawa Pening Bebas Eceng Gondok,", https://regional.kompas.com/read/ 2011/08/03/1914388/2030.Rawa.Pening.Bebas.Ecen g.Gondok., diakses 10 April 2019.

Asrofi, M. , Abral, H., Kasim, A. \& Pratoto, A., (2017), XRD and FTIR Studies of Nanocrystalline Cellulose from Water Hyacinth (Eichornia crassipes) Fiber, Journal of Metastable and Nanocrystalline Materials, Vo. 29., 9-16.

Asrofi, M., Abral, H., Kasim. A., Pratoto, A., Mahardika, M., \& Hafizulhaq, F. (2018) Mechanical Properties of a Water Hyacinth Nanofiber Cellulose Reinforced Thermoplastic Starch Bionanocomposite: Effect of Ultrasonic Vibration during Processing. Fibers, 6(40), $1-9$.

Asrofi, M., Abral, H., Putra, Y.K., Sapuan, S.M. \& HyunJoong Kim. (2018) Effect of duration of sonication during gelatinization on properties of tapioca starch water hyacinth fiber biocomposite. International Journal of Biological Macromolecules, 108, 167176.

Athijayamani, A., Thiruchitrambalam, M., Manikandan, V., \& Pazhanivel, D. (2009) Mechanical properties of natural fibers reinforced polyester hybrid composite, Int J Plast Technol, 13(1), 1-12.

Bahra, M.S., Gupta, V. K. \& Aggarwal, L. (2017). Effect of Fibre Content on Mechanical Properties and Water Absorption Behaviour of Pineapple/HDPE Composite. Materials Today: Proceedings, Vol 4 (2), Part A, 3207-3214.
Balachandar, M., Vijaya Ramnath, B., Barath, R. \& Bharath Sankar, S., (2019) Mechanical Characterization of Natural Fiber Polymer Composites. Materials Today: Proceedings, Vol. 6 (2), 1006-1012.

Baley, C., Gomina, M., Breard, J., Bourmauda, A., \& Davies, P. (2019). Variability of mechanical properties of flax fibres for composite reinforcement. A review., Industrial Crops \& Products, Article In Press Available online 22 November 2019.

Bhuvaneshwari, M. \& Sangeetha (2017). Development of Water Hyacinth nonwoven fabrics for thermal insulation. Journal on Future Engineering \& Technology, 13(1), $22-29$.

Bismarck, A., Mishra, S., \& Lampke, T., (2005). Plant fibers as reinforcement for green composites. In A. K. Mohanty, M. Misra, \& L. T. Drzal (Eds.), Natural Fibers, Biopolymers, and Biocomposites (p. 38). Boca Raton, FL: CRC Press.

Bordoloi, S., Kashyap, V., Garg, A., Sreedeep, S., Wei, L. \& Andriyas, S. (2018) Measurement of mechanical characteristics of fiber from a novel invasive weed: A comprehensive comparison with fibers from agricultural crops, Measurement, 113, 62-70.

Cai, M., Takagi, H., Nakagaito, A.N., Yan Li \& Waterhouse, G.I.N., (2016). Effect of alkali treatment on interfacial bonding in abaca fiber-reinforced composites. Composites Part A: Applied Science and Manufacturing, Vol. 90, 589-597.

Cheng, S., Lau, K., Liu,T, Zhao,Y, Lam, P.M. \& Yin, Y. (2009) Mechanical and thermal properties of chicken feather fiber/PLA green composites. Composites Part $B, 40(7), 650-654$.

Chonsakorn, S., Srivorradatpaisan, S., \& Mongkholrattanasit, R. (2018) Effects of different extraction methods on some properties of water hyacinth fiber. Journal of Natural Fibers, 1 - 11.

Choudhary, A. K., Chelladurai, H., Kannan, C. (2015) Optimization of combustion performance of bioethanol (water hyacinth) diesel blends on diesel engine using response surface methodology. Arabian

Journal for Science and Engineering. 40, 3675- 3695.

Deb, A., Das., S., Mache, A. \& Laishram, R. (2017) A study on the mechanical behaviors of jute-polyester composites, Procedia Engineering 173, 631-638.

Dittenber, D. B. \& Ganga Rao, H. V. (2011) Critical review of recent publications on use of natural composites in infrastructure. Composites Part A, Applied Science and Manufacturing, 43(8), 1419-1429.

Elanchezhiana, C., Ramnath, B.V., Ramakrishnan, G., Rajendrakumar, M., V. Naveenkumar, V., \& Saravanakumar, M.K. (2018) Review on mechanical properties of natural fiber composites. Materials Today (Proceedings 5), 1785-1790. 


\section{TEKNIK, 41 (1), 2020, 36}

European and Mediterranean Plant Protection Organization (EPPO), (2008). Data sheets on quarantine pests: Eichhornia crassipes, Bulletin OEPP/EPPO Bulletin, 38, 441-449

Faruk, O., Bledzkia, A.K., Fink, H, \& Sain, M. (2012) Biocomposites reinforced with natural fibers: 2000 2010, Progress in Polymer Science, 37, 1552- 159.

Fiore, V., T.Scalici, T., Nicoletti., F., Vitale, G., Prestipino, M., Valenzaa, A. (2016) A new eco-friendly chemical treatment of natural fibres: Effect of sodium bicarbonate on properties of sisal fibre and its epoxy composites. Composites Part B: Engineering, Vol. $85,150-160$.

Gashti, M.P. (2013) Effect of colloidal dispersion of clay on some properties of wool fiber. Journal of Dispersion Science and Technology, 34(6), 853-858.

Giridharan, R., (2019). Preparation and property evaluation of Glass/Ramie fibers reinforced epoxy hybrid composites. Composites Part B: Engineering, Vol. $167,342-345$.

Gupta, A. \& Balomajumder, C. (2015) Removal of Cr(VI) and phenol using water hyacinth from single and binary solution in the artificial photosynthesis chamber. Journal of Water Process Engineering. 7, 74-82.

Gao, J., Chen, L., Yan, Z., Wang, L.(2013) Effect of ionic liquid pretreatment on the composition, structure and biogas production of water hyacinth (Eichhornia cassipes). Bioresource Technology. 132, 361- 364.

Guo, A., Sun, Z., Satyavolu, J., (2019). Impact of chemical treatment on the physiochemical and mechanical properties of kenaf fibers. Industrial Crops and Products, Volume 141, Article 111726.

Hamidon, M.H., Sultan, M.T.H., Ariffin, A.H., Shah, A.U.M., (2019). Effects of fibre treatment on mechanical properties of kenaf fibre reinforced composites: a review. Journal of Materials Research and Technology, Vol. 8(3), 3327-3337.

Hanamanagouda, Keerthi Gowda, B.S, Easwara Prasad, G.L. \& Velmurugan, L. (2006) Mechanical Properties of Raw Jute Polyester Composite, International Journal of Fiber and Textile Research, 6(1), 20-24.

Hidayati, N., Soeprobowati, T. R., \& Helmi, M., 2018, The evaluation of water hyacinth (Eichhornia crassiper) control program in Rawapening Lake, Central Java Indonesia, IOP Conf. Series: Earth and Environmental Science, 142, 1-5

Huda, N.N., Nath, P., Al Amin, Md. \& Rafiquzzaman, Md. (2017) Charpy Impact Behavior of Water Hyacinth Fiber Based Polymer Composite. Journal of Material Science \& Manufacturing Technology, 2(2), 1- 13.

Indrayati, A. \& Hikmah, N.I. (2018) Prediksi Sedimen Danau Rawa Pening Tahun 2020 Sebagai Dasar
Reservasi Sungai Tuntang Berbasis Sistem Informasi Geografis, Prosiding Seminar Nasional Geografi UMS IX 2018. 543 - 552.

Jawaid, M., \& Khalil, H. P. S. (2011). Cellulosic/synthetic fibre reinforced polymer hybrid composites: A review. Carbohydrate Polymers, 86(1), 1-18.

Jiang, L. \& Hinrichsen, G. (1999). Flax and cotton fi ber reinforced biodegradable polyester amide. Die Angewandte Makromolekulare Chemie. 268, 13-17.

Karyanik \& Sari, N.H. (2016) Analisis sifat mekanik material komposit eceng gondok berbahan filler ampas singkong dengan matrik polyester, Jurnal Rekayasa Energi Manufaktur, Vol. 1 (1), 17-22.

Kabir, M.M., Wang, H., Lau, K.T. \& Cardona, F. (2012), Chemical treatments on plant-based natural fibre reinforced polymer composites: An overview. Composites: Part B, 43, 2883-2892.

Karina, M., Onggo, H., Syampurwadi, A, (2007) Physical and Mechanical Properties of Natural Fibers Filled Polypropylene Composites and Its Recycle, Journal of Biological Science, 7(2), 393-396.

Khankham, P., Nhuapeng, W. \& Thamjaree, W. (2017), Fabrication and Mechanical Properties of the Biocomposites between Water Hyacinth Fiber and Paper Mulberry. Key Engineering Materials, 757, 73-77.

Kian, L.K., Saba, N., Jawaid, M., Sultan, M. T. H., (2019). A review on processing techniques of bast fibers nanocellulose and its polylactic acid (PLA) nanocomposites. International Journal of Biological Macromolecules, Volume 121,1314-1328.

$\mathrm{Ku}, \mathrm{H}$. , Wang, H., Pattarachaiyakoop, N. \& Trada, M. (2011) A review on the tensile properties of natural fiber reinforced polymer composites. Composites: Part B, 42, 856-873.

Kuang,X., Guan, S., Rodgers, J., \& Yu, C., (2017). Study on length distribution of ramie fibers, The Journal of The Textile Institute, Vol 108 (11), 1-10.

Madhu, P., Sanjay, M. R., Senthamaraikannan, P., Pradeep, S., Saravanakumar, S. S. \&Yogesha, B., (2018) A review on synthesis and characterization of commercially available natural fibers: Part-II. Journal of Natural Fibers, 1-13.

Maurya, H. M., Gupta, M.K., Srivastava, R.K. \& Singh, H. (2015) Study on the mechanical properties of epoxy composite using short sisal fibre, Materials Today: Proceedings, 2, 1347 - 1355.

Manimaran, P., Senthamaraikannan, P., Murugananthan, K., \& Sanjay, M. R. (2018). Physicochemical properties of new cellulosic fibers from Azadirachta indica plant. Journal of Natural Fibers, 15(1), 29-38.

Mohanty, A.K., Misra, M., Hinrichsen, G., (2000). Biofibres, biodegradable polymers and biocomposites: An overview, Macromolecular Materials and Engineering, 276/277, 1-24. 


\section{TEKNIK, 41 (1), 2020, 37}

Nam, S. dan Netravali, A.N., (2006). Green Composites. I. Physical Properties of Ramie Fibers for Environment-friendly Green Composites, Fibers and Polymers, Vol.7, No.4, 372-379.

Padmanabhan, R.G., Arun, N., S. Reddy, K. B. S., (2016). Investigation of Mechanical Behavior of Water Hyacinth Fiber / Polyester with Aluminium Powder Composites, International Journal of Application or Innovation in Engineering \& Management, Volume $5(2), 56-62$.

Paridah, M. T., Basher, A. B., SaifulAzry, S., \& Ahmed, Z. (2011). Retting process of some bast plant fibres and its effect on fibre quality: A review. BioResources, 6(4), 5260-5281.

Pickering, K.L., Efendy, M.G.A. \& Le, T.M. (2016) A review of recent developments in natural fibre composites and their mechanical performance, Composites: Part A, 83, 98-112.

Potiyaraj, P., Panchaipech, P. \& Chuayjuljt, S. (2001) Using Water-Hyacinth Fiber as a filler in natural rubber. Journal of Scientific Research, Chulalongkorn University, 26(1), $11-19$.

Prasad, A.V.R., Rao, K.M. \& Nagasrinivasulu, G. (2009) Mechanical properties of banana empty fruit bunch fibre reinforced polyester composites. Indian Journal of Fibre \& Textile Research, 4, 162-167.

Prasetyaningrum, A., Rokhati, N., \& Rahayu, A. K. (2009) Optimasi proses pembuatan serat eceng gondok untuk menghasilkan komposit serat dengan kualitas fisik dan mekanik yang tinggi, Riptek, Vol.3(1), 45 50.

Rafiquzzaman, Md., Imran Hossain, Md \& Akydur Rahman (2017) Mechanical properties of agricultural byproduct polymer composites. Journal of Material Science and Manufacturing Technology, 2(2), 1-14.

Rani, S., Sumanjit, K., Mahajan, R. K. (2015) Comparative study of surface modified carbonized Eichhornia crassipes for adsorption of dye safranin. Separation Science and Technology. 50, 2436- 2477.

Ramirez, N.F., Hernandez, Y.S., Cruz de Leon, J., Vasquez Garcia, S. R., Domratcheva Lvova, L., \& Garcia Gonzalez, L., (2015). Composites from Water Hyacinth (eichhornea crassipe) and polyester resin, Fibers and Polymers, Vol.16(1), 196-200.

Ribeiro, A., Pochart, P., Day, A., Mennuni, S., Bono, P., \& Baret, J. L. (2015). Microbial diversity observed during hemp retting. Applied Microbiology and Biotechnology, 99(10), 4471-4484.

Romanova, T. E.; Shuvaeva, O. V.; Belchenko, L. A. (2016). Phytoextraction of trace elements by water hyacinth in contaminated area of gold mine tailing. International Journal of Phytoremediation. 18 (2), 190- 194.
Romanzini, D., Junior, H.L.O, Amico, S.C., \& Zattera, A.J. (2012) Preparation and characterization of ramieglass fiber reinforced polymer matrix hybrid composites, Materials Research, 15(3): 415-420.

Saha, M., (2011) Mechanical characterization of water hyacinth reinforced polypropylene composites, thesis Master Of Science In Mechanical Engineering, Department Of Mechanical Engineering Bangladesh University Of Engineering And Technology.

Salas-Ruiz, A. \& Barbero-Barrera, M. (2019) Performance assessment of water hyacinth-cement composite. Construction and Building Materials, 211, 395-407.

Sanjay, M. R., \& Siengchin, S. (2018). Natural fibers as perspective materials. KMUTNB: International Journal of Applied Science and Technology, 11, 233.

Sanjay, M. R., Madhu, P., Jawaid, M., Senthamaraikannan, P., Senthil, S., \& Pradeep, S. (2018). Characterization and properties of natural fiber polymer composites: A comprehensive review. Journal of Cleaner Production, 172, 566-581.

Sanjay, M.R., Siengchin, S, Parameswaranpillai, J., Jawaid, M., Catalin Iulian Pruncu, C.I. \& Khan, A., 2019, A comprehensive review of techniques for natural fibers as reinforcement in composites: Preparation, processing and characterization. Carbohydrate Polymers, 207, 108-121.

Sapci, Z. (2013) The effect of microwave pretreatment on biogas production from agricultural straws, Bioresource Technology., 128, 487-494.

Saputra, A.H., Difandra, A. \& Pitaloka, A.B. (2013) The effect of surface treatment on composites of water hyacinth natural fiber reinforced epoxy resin. Advanced Materials Research, 651, 480-485.

Siengchin, S., 2017. Editorial corner-a personal view Potential use of'green'composites in automotive applications. eXPRESS Polymer Letters, Vol. 11(8), 600-600.

Simanjuntak, M.P (2013) Sifat mekanik komposit terhadap fraksi volume serat eceng gondok bermatriks polyester, Jurnal Einstein, Vol. 1(2), 76-87.

Simbolon, D. H. (2018) Sifat mekanik komposit polietilena daur ulang dengan filler serat eceng gondok, Prosiding Simposium Fisika Nasional(SFN-XXXI), Medan, 19 September 2018.

Simonassi, N. T., Pereira, A. C., Monteiro, S. N., Margem, F. M., Rodríguez, R. J. S., Deus, J. F. de, \& Drelich, J. (2017). Reinforcement of polyester with renewable ramie fibers. Materials Research, 20(2), 51-59.

Sindhu, R., Binod, P., Pandey, A., Madhavan, A., Alphonsa, J.A., Vivek, N., Gnansounou, E., Castro, E. \& Faraco, V. (2017) Water hyacinth a potential source for value addition: an overview. Bioresource Technology, 230, 152-162.

Sivasankari. B. \& David Ravindran.A. (2006) A study on chemical analysis of water hyacinth (eichornia 


\section{TEKNIK, 41 (1), 2020, 38}

crassipes), water lettuce (pistia stratiotes). International Journal of Innovative Research in Science, Engineering and Technology. 5(10), 17566 -17570 .

Sood, M. \& Dwivedi, G. (2018) Effect of fiber treatment on flexural properties of natural fiber reinforced composites: A review. Egyptian Journal of Petroleum, 27, 775-783.

Sundari, M. T. dan Ramesh, A., (2012) Isolation and characterization of cellulose nanofibers from the aquatic weed water hyacinth-Eichhornia crassipes, Carbohydrate Polymers 87, 1701- 1705.

Supri, A.G. \& Lim, B.Y. (2009) Effect of treated and untreated filler loading on the mechanical, morphological, and water absorption properties of water hyacinth fibers-low density polyethylene composites. Journal of Physical Science, 20(2), 8596.

Supri, A.G., \& Ismail, H. (2010) The Effect of NCO-Polyol on the Properties of low-density polyethylene/water hyacinth fiber (eichhornia crassiper), Composites Polymer-Plastics Technology and Engineering, 49: 766-771.

Supri, A.G. \& Ismail, H. (2011). The effect of isophorone diisocyanate-polyhydroxyl groups modified water hyacinth fibers (eichhornia crassiper) on properties of low density polyethylene/ acrylonitrile butadiene styrene (LDPE/ABS) Composites, Polymer-Plastics Technology and Engineering, 50, 113-120.

Supri, A.G., Tan, S.J., Ismail, H., The, P.L. 2013, Enhancing interfacial adhesion performance by using poly(vinyl alcohol) in (low-density polyethylene)/ (natural rubber)/(water hyacinth fiber) composites, Journal of Vinyl \& Additive Technology, 47-54.

Suryana, D., Junaidi, A., \& Rizki, M. (2018) Pengaruh komposisi komposit serat-serat eceng gondok dan pasir silika terhadap uji impact dan uji tarik untuk point panjat dinding, Jurnal Austenit, 10(2), 15-20.

Takagi, H. \& Ichihara, Y. (2004). Effect of Fiber Length on mechanical properties of green composites using a starch-based resin and short bamboo fibers. JSME International Journal, 47(4), 551-555.

Tan, S. J., Supri, A. G., Chong, K. M. (2015) Properties of recycled high density polyethylene/water hyacinth fiber composites: Effect of different concentration of compatibilizer. Polymer Bulletin. 72, 2019- 2031.

Tan, S. J., \& Supri, A. G. (2016). Properties of low-density polyethylene/natural rubber/water hyacinth fiber composites: the effect of alkaline treatment. Polymer Bulletin, 73(2), 539-557.

Teygeler, R. (2000) Water hyacinth paper. Contribution to a sustainable future, Paper and Water. Gentenaar \& Torley Publishers, 168-188.
Thakur, V. K., \& Thakur, M. K. (2014) Processing and characterization of natural cellulose fibers/thermoset polymer composites. Carbohydrate Polymers, 109, $102-117$.

Thomas, M. G., Abraham, E., Jyotishkumar, P., Maria, H. J., Pothen, L. A. \& Thomas, S. (2015) Nanocelluloses from jute fibers and their nanocomposites with natural rubber: Preparation and characterization. International Journal of Biological Macromolecules, 81, 768-777.

Thi, B. T. N., Thanh, L. H. V., Phuong Lan, T. N., Dieu Thuy, N. T., Ju, Yi-Hsu, (2017), Comparison of some pretreatment methods on cellulose recovery from water hyacinth (eichhornia crassipe). Journal of Clean Energy Technologies, Vol. 5 (4), 274-279.

Ticoalu, A., Aravinthan, T. \& Cardona, F., (2010). A review of current development in natural fiber composites for structural and infrastructure applications, Southern Region Engineering Conference, 11-12 November 2010, Toowoomba, Australia.

Tumolva, T., Ortenero, J. \& Kubouchi, M. (2013) Characterization and treatment of water hyacinth fibers for NFRP composites, The 19th International Conference on Composite Materials, July 28 to August 2, 2013, Montreal, Canada.

Umardani, Y., \& Pramono, C. (2009) Pengaruh larutan alkali dan etanol terhadap kekuatan tarik serat enceng gondok dan kompatibilitas serat enceng gondok pada matrik unsaturated polyester Yukalac tipe 157 BQTN-EX, Rotasi, Vol 11(2), 24-29.

Valadez-Gonzalez, A., Cervantes-Uc, J. M., Olayo, R., Herrera-Franco, P. J. (1999) Effect of fiber surface treatment on the fiber-matrix bond strength of natural fiber reinforced composites. Composites Part B: Engineering, Vol. 30 (3), 309-320.

Varghese, A. M., \& Mittal, V. (2018) Surface modification of natural fibers. Biodegradable and Biocompatible Polymer Composites, 5, 115-155.

Venkateshwaran, N., Elaya Perumal, A. \& Jagatheeshwaran, M.S. (2011). Effect of fiber length and fiber content on mechanical properties of banana fiber/epoxy composite, Journal of Reinforced Plastics and Composites, 30(19), 1621-1627.

Verma, R. dan Shukla, M., (2018). Characterization of mechanical properties of short kenaf fiber-hdpe green composites. Materials Today: Proceedings, Vol. 5(2), Part 1, 3257-3264.

Widhata, D., Ismail, R., Sulardjaka, (2019). Water hyacinth (eceng gondok) as fibre reinforcement composite for prosthetics socket, IOP Conf. Series: Materials Science and Engineering 598, 012127.

Wijayanti, M., Yahya, I., Harjana, Kristiani, R. \& Muqowi, E. (2015) Analisis kinerja akustik panel gedek bambu dengan sisipan komposit eceng gondok, Jurnal Fisika dan Aplikasinya, Vol. 11 (2), 86-90. 


\section{TEKNIK, 41 (1), 2020, 39}

Yuan, Jian-Min., Feng, Yan-Rong., He, Li-Ping., (2016). Effect of thermal treatment on properties of ramie fibers, Polymer Degradation and Stability, Vol.133, 303-311.

Yusof, Y., Yahya, S.A., Adam, A., (2015). Novel technology for sustainable pineapple leaf fibers productions. Procedia CIRP, Vol. 26, 756-760.
Zini, E., dan Scandola, M. (2011). Green composites: An overview. Polymer Composites, 32(12), 1905-1915.

Zwane, P.E., Ndlovu, T., Mkhonta, T. T., Masarirambi, M. T., Thwala, J. M. (2019) Effects of enzymatic treatment of sisal fibres on tensile strength and morphology, Scientific African, Vol. 6, Article e00136. 